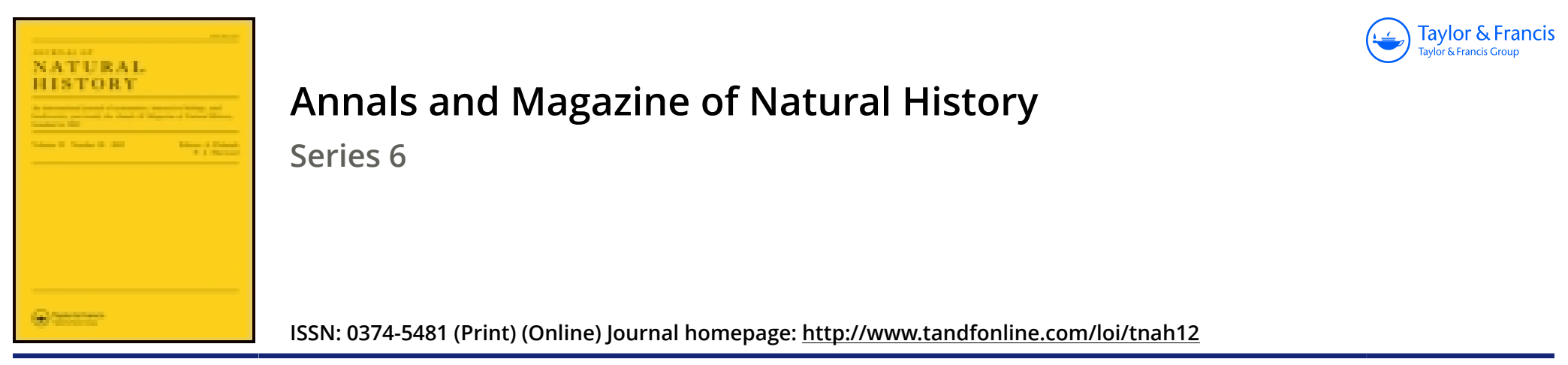

\title{
XXXI.-Descriptions of new species of African Lycænidæ, chiefly from the collections of Dr. Staudinger and Mr. Henley Grose Smith
}

\author{
W.F. Kirby F.L.S. F.E.S.
}

To cite this article: W.F. Kirby F.L.S. F.E.S. (1890) XXXI.-Descriptions of new species of African Lycænidæ, chiefly from the collections of Dr. Staudinger and Mr. Henley Grose Smith , Annals and Magazine of Natural History, 6:33, 261-274, DOI: 10.1080/00222939008694032

To link to this article: http://dx.doi.org/10.1080/00222939008694032

曲 Published online: 12 Oct 2009.

Submit your article to this journal $\pi$

Џll Article views: 3

Q View related articles $₫$

4 Citing articles: 2 View citing articles 지 
duced at their inner apex. The prothorax is fully rounded in the middle at the sides, is narrowed at the base, and still more at the apex; the whole space above between the anterior and posterior transverse grooves is covered with numerous rather short and irregular ridges *. Mr. Fry had placed this species in the genus Massicus, and I have no doubt that this is the best place for it.

[To be continued.]

XXXI.-Descriptions of new Species of African Lycænidæ, chiefly from the Collections of Dr. Staudinger and $\boldsymbol{M r}$. Henley Grose Smith. By W. F. KIRBY, F.L.S., F.E.S., \&c.

A LARGE number of African Lycænidæ have been kindly sent over to Mr. H. Grose Smith by Dr. Staudinger to be figured in 'Rhopalocera Exotica,' several of which have already been published in that work or will appear immediately. By far the larger number, however, cannot be figured for some little time, and I therefore publish descriptions, pending the appearance of the figures. Nearly all belong to genera which have already been more or less fully treated of in the section of our work devoted to African Lycænidæ.

\section{Genus Asladga, gen. nov.}

Wings short and broad, very densely scaled; anterior wings strongly curved outwards in the middle of the hind margin; posterior wings with a concavity on the inner margin at the anal angle. Anterior wings with the subcostal nervure five-branched, the first two branches emitted near together before the end of the cell and parallel, the other three short and emitted near the apex of the wing; the third and fourth parallel, running into the costa before the apex, the fifth running to the hind margin just below the apex.

Exp. 1 inch.

\section{Aslauga marginalis.}

Male.-Upperside tawny, with the hind margins and the costa of the anterior wings rather broadly brown.

* Since writing the abore I have seen a second male specimen in the possession of Mr. Oliver Janson. In this the prothorax is much more regularly transversely wrinkled, and in that respect presents little difference from venustus, Pasc.

Ann. \& Mag. N. Hist. Ser. 6. Vol. vi. 
Underside uniform yellowish tawny.

Body brown, abdomen tawny (antennæ wanting).

$\mathrm{Hab}$. Sierra Leone.

In the collection of Mr. Henley Grose Smith.

Allied to Liphyra vininga, Hew., which is evidently congeneric.

Exp. $1 \frac{1}{6}$ inch.

Upperside as in $A$. zymna, Westw., but posterior wings less produced.

Underside : Anterior wings white, grey towards the costa and hind margin, with two grey, transverse oval spots in the cell and two white submarginal festooned lines towards the hind margin. Posterior wings pearly grey, with six or seven white transverse lines formed of connected lunules.

Hab. Barombi, Cameroons (Preuss).

In the collection of Dr. Staudinger.

\section{Pseuderesia cellularis.}

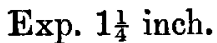

Male.-Upperside rich tawny, the base and costa of the anterior wings and the inner portion of the posterior wings irrorated with brown; apical third of anterior wings and the hind margins of all the wings rather broadly bordered with black. Anterior wings with some small spots towards the base, a very large one at the end of the cell, and a few others towards the dark border, from which the larger ones are hardly separated.

Underside: Anterior wings with the costa, apex, and hind margin blackish, densely irrorated with yellow; the lower part of the base is of a dull black, the disk being fulvous; the spot at the end of the cell is well marked; there is an oblique row of large connected spots towards the apex, beyond the cell, and a row of small, sagittate, submarginal black spots before the fringes. Posterior wings dirty yellow, with a circle of five large round spots near the base, having a smaller one in the centre; besides these, there is a large one on the middle of the costa and a small one on the middle of the inner margin; hind margin preceded by a festooned black line, within which is a row of large spots.

Female.-Upperside similar, bnt of a paler fulvous, with narrower borders, and with fewer traces of the submarginal black spots.

Underside of a clearer yellow, with the spots and black 
markings smaller; on the posterior wings the central spot in the circle is absent.

HIab. Cameroons.

In the collection of Dr. Staudinger.

Allied to $P$. (Liptena) parva, Kirb.

\section{Pseuderesia paucipunctata.}

Exp. $1 \frac{1}{4}$ inch.

Female.-Upperside tawny; anterior wings with the apex blackish, from two thirds of the length of the costa to two thirds of the length of the hind nargin, beyond which the border is continued as a narrow line to the hinder angle. Posterior wings with the fringes blackish. A large spot at the end of the cell on all the wings.

Underside tawny yellow, with the costa and apex of anterior wings and the whole of the posterior wings irrorated with brown; besides the spots closing the cells, there is one in the cell of the anterior wings and a smaller one above the cell of the posterior wings. Posterior wings with very indistinct traces of four submarginal dusky spots, one towards the tip and the other three towards the anal angle.

$H a b$. Cameroons.

In the collection of Dr. Staudinger.

Possibly an extreme variety of P. Petreia, Hew. (of which T. Preussi, Staud., is a synonym), which seems to vary considerably in depth of colouring and in the extent of the dark border on the posterior wings, and to a less extent in the number of spots.

\section{Pseuderesia turbata.}

Exp. a little over an inch.

Male.-Upperside reddish tawny, the costa and tip of anterior wings and the hind margins rather broadly brown.

Underside paler tawny. Anterior wings with two black spots in the cell, the costa irregularly black, throwing out a broad band at the end of the cell; the paler apex is cut off by another oblique irregular band, and the costa and the space between this band and the hind margin are likewise spotted with black; fringes black, and a submarginal black line on the upper part of the wing. Posterior wings more buff; two spots on the costa above the cell, one large spot above, and two in the cell, which is itself closed by a black line, and three spots below the cell; the rest of the wing is marked with large irregular black blotches. The black fringes are preceded by a zigzag black line. 
Hab. Cameroons (Preuss).

In the collection of Dr. Staudinger.

Allied to $P$. parva, Kirb., and $P$. petreia, Hew.

\section{Pseuderesia similis.}

Exp. a little over an inch.

Female.-Upperside nearly as in P. turbata, but the costa of the posterior wings brown for two thirds of its length.

Underside : Anterior wings red; costa black for one third of the breadth of the wing to beyond the cell; then the reddish space runs up, separating it from the apical area, which is marked with two much dentated grey lines; the border itself is grey, edged within by a black line on its upper half. Posterior wings grey, with a black spot on the costa, two very large subcostal spots, three in the cell, the last linear, closing it, and three below; the marginal area is occupied by three rows of black zigzag spots separated by two rows of grey ones. Fringes grey, edged within by a black and then by a grey line.

Hab. Cameroons (Preuss).

In the collection of Dr. Staudinger.

This might be the female of $P$. turbata, but the marginal markings of the posterior wings beneath are very different.

\section{Pseuderesia debora.}

Exp. $1 \frac{1}{10}$ inch.

Male.-Upperside dull black, the incisions scaled with white. Posterior wings with a large orange blotch extending from the second submedian nervule to the inner margin just above the anal angle.

Underside: Anterior wings more of a slate-colour ; costa and hind margin dusted with grey, inner margin paler, with a whitish blotch at the hinder angle; three red spots placed obliquely near the apex of the wings. Posterior wings dull black dusted with grey; a broad red band formed of three nearly connected spots crosses the middle of the cell, but does not extend to the costa or inner margin; within this is a row of smaller spots, three red and two black, placed alternately, and at the base is another red spot; beyond each of the upper and lower red spots of the band stands a black spot, and atter these another row of three disconnected red marks, a large one near the costa, a line closing the cell, and a small spot below; beyond the line is another large red spot; beyond these is a series of seven red spots edged within with black ones (and slightly edged with black on the outside too), one 
on the costa, three connected spots, placed much nearer the hind margin, and another series of three connected spots, running towards the anal angle.

Hab. Barombi, Cameroons (Preuss).

In the collection of Dr. Staudinger.

\section{Pseuderesia dinora.}

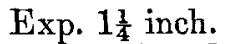

Upperside reddish tawny (lighter in the female than in the male), with the base and costa blackish and the apex of anterior wings broadly, and the hind margin below and that of the posterior wings rather narrowly, black ; cell of the anterior wings closed by a large round black spot, not separated from the black colour of the costa; that of the posterior wings closed by a short black bar.

Underside: Anterior wings mostly black, costa irrorated with pale yellow in patches; apex with a large yellow blotch, from which smaller yellow spots extend down the hind margin; disk towards the hinder angle with a large fulvous blotch, spotted and irrorated with black.

Posterior wings grey, yellow at the base and with a yellow blotch at the tip; between this and the anal angle is a thick black, festooned, submarginal line, enclosing three small yellow spots; within this are two large red spots, and within these an angulated row of seven large spots from the costa to the inner margin; the third is red and adjoins a black spot, within which again is a large black spot closing the cell ; in the cell is a small spot, and there are two or three more large and small ones towards the costa, and again towards the inner margin.

In the female the markings are rather more suffused, and one of the large spots on the costa of the posterior wings near the base adjoins a red dot.

$H a b$. Cameroons.

In the collection of Dr. Staudinger.

Very distinct from the other species of the group of $P$. parva by the three large red spots on the underside of the posterior wings.

\section{Durbania gerda.}

Exp. 1 inch.

Female.-Upperside orange-tawny, hind margins slightly scalloped. Anterior wings paler on the disk, with a brown spot at the end of the cell, the costa slightly irrorated with brown; the apical area with a brown shade running down- 
wards parallel to the hind margin, which it does not touch, except at the apex ; fringes marked with a blackish interrupted line at their base, swelling into more distinct spots at the extremities of the nervures. Posterior wings nearly uniform in colour; fringes slightly speckled with blackish.

Underside: Anterior wings rather paler than above, irrorated with black on the costa above the cell; a large brown spot at end of cell; at one third of the distance between this and the apex are a series of four oblong spots placed obliquely, two larger and darker ones on the costa, nearly connected, and two others below; marginal area irrorated with brown, and with a submarginal row of long blackish spots on a paler ground, dusted with grey; fringes preceded by a broken blackish line, most continuous below. Posterior wings brownish tawny, with rather indistinct markings; two dusky spots above the cell, two below, and one at the extremity; beyond the cell are two festooned lines of connected lunules, the outermost preceding a more continuous sexies of darker lunules, the space between dusted with grey; a series of blackish spots at the extremities of the nervures. white.

Body tawny above; legs and antennæ black, spotted with

Hab. Barombi (Preuss).

In the collection of Dr. Standinger.

Allied to D. aslauga, Trim.

\section{Larinopoda sylpha.}

Exp. about 1 inch.

Semitransparent white, with iridescent ashy borders along the costa of the anterior wings and all the hind margins, ceasing at the anal angle of the posterior wings; the costal border of the anterior wings sends off a projection at the end of the cell, most strongly marked in the female.

Antennæ black, ringed with white; club long, slender, pointed; legs and under surface of abdomen yellow.

Sexes nearly similar.

Differs from our figure of L. muhata, Dew., o (Rhop. Ex. Afr. Lyc. pl. ii. figs. 1, 2), by the absence of the black spot on the posterior wings.

Hab. Barombi, Cameroons (Preuss).

In the collection of Dr. Staudinger.

\section{Larinopoda opaca.}

Exp. rather over an inch.

Opaque white, with rather broad brown border on the costa 
of anterior wings and on the hind margins of all the wings; a large oval spot at the end of the cell of the posterior wings; on the under surface the border does not quite reach the hinder angle of the anterior wings. Fringes grey, with a blackish line at the base, separated from the broad border by a whitish submarginal line.

Legs yellow ; abdomen white : antennæ black, ringed with white; club black, tipped with yellow.

Hab. Cameroons (Preuss).

In the collection of Dr. Staudinger.

\section{Tingra lavinia.}

Exp. $1 \frac{1}{4}$ inch.

Male.-Upperside white, with rather large black spots on the costa towards the apex of fore wings, at the ends of all the cells, and at the ends of the nervures on all the hind margins, and one nearer the base above the cells; under this, on the anterior wings only, is occasionally another spot in the cell on the underside; extreme base of the wings slightly stained with yellow; apex of anterior wings slightly bordered with ashy above.

In the collections of the British Museum (Gaboon) and Dr. Staudinger (Ogowe).

Allied to T. torrida, Kirb., but a larger, paler, and broaderwinged insect.

\section{Tingra laura.}

Exp. $1 \frac{1}{4}$ to $1 \frac{1}{2}$ inch.

Male.-Upperside white, tinged with tawny at base. Anterior wings: costa irrorated with black, tip ashy to the lowest submedian nervule, its upper part edged within with three black spots, nearly lost in the ashy colouring; another spot at end of cell, two small ones in the cell, on one side only, and two on the disk opposite the lowest part of the border. Posterior wings with a spot on the costa above the cell, and another at its extremity; other spots on the under surface showing faintly through.

Underside white, tinged with yellow on the costa and at the apex of the anterior wings, and on the posterior wings, chiefly at base and tip; hind margins spotted with black on the nervures. Anterior wings with a row of spots above the cell (only one distinct, the costa being irrorated with black), one at the end of the cell, and two submarginal rows at the apex, the outermost (nearly straight) of three larger, and the innermost (oblique) of four smaller spots. Posterior wings 
with a small spot at base of cell, a large one on the costa above the cell, a small one below the cell, and another at its extremity, beyond which is an angulated row of six spots running from the costa, and a shorter row of three between the upper ones and the apex.

Female.-Upperside white; apex of anterior wings rather broadly ashy, but this colour ceases on the hind margin at the lowest median nervule; a conspicuous black spot at the end of the submedian nervure, and of all the nervures of the posterior wings except the first branch of the subcostal; the only other distinct spots on the upperside are those at the ends of the cells and a small one in the cell of the anterior wings, but some of the others are also slightly indicated.

Underside white, the ends of the nervures marked with small black spots. Anterior wings with a row of four small subcostal spots, two spots in the cell besides the larger one at its extremity, and another in the fork of the two lower median nervules. Posterior wings with a large spot above the middle of the cell, a small one at the base of the cell, a large one at its extremity, and one in the fork of the nervures below; a submarginal row of six small spots, angulated outwards in the middle, commencing with a spot larger than the others on the costa.

Antennæ black, tipped with tawny in both sexes.

Hab. Lagos.

In the collection of Dr. Staudinger.

Exp. $1 \frac{1}{4}$ inch.

Tingra fatima.

White, slightly stained with orange at the base of the costa. Anterior wings with the apex dark ashy to below the upper submedian nervule; a large black spot at the end of the cell of all the wings.

Underside white, with black discoidal spots, and a black line at the base of the fringes; within it is a second on the upper half of the anterior wings.

Hab. Cameroons.

In the collection of Dr. Staudinger.

The sexes do not differ.

\section{Teriomima decipiens.}

Exp. rather more than 1 inch.

Upperside white, costa (narrowly, but most broadly towards the base) and apex, as far as the upper branch of the submedian nervure, ashy. 
Underside more inclining to yellowish, with two submarginal yellow stripes in the male and one in the female; fringes of anterior wings edged with a black line, as far as the ashy patch of the wing extends on the upper surface.

Antennæ black, slightly spotted with white; club long and rather slender.

Hab. Barombi, Cameroons (Preuss).

In the collection of Dr. Staudinger.

The sexes hardly differ.

\section{Teriomima delicatula.}

Exp. rather under an inch.

Male.-Upperside white, the apical third of the anterior wings ashy. Posterior wings with a few small marginal dots.

Underside tinged with yellow on the posterior wings and on the costa and apex of the anterior wings. Anterior wings with a row of ashy spots on the costa, an oblique row on the inner side of the yellowish apical shade, and a spot at the end of the cell and a small dot within it. Posterior wings with a spot in the cell, spots above and below, and a streak at the end of the cell, and two rows of small obsolete spots nearer the hind margins.

Antennæ black, ringed with white; club long and rather slender.

Hab. Usugara.

In the collection of Dr. Staudinger.

Closely allied to T. subpunctata, Kirb., but with the spots much smaller, less numerous, and differently arranged.

\section{Teriomima serena.}

Exp. about 1 inch.

Upperside yellow; apex of anterior wings black, from two thirds of the length of the costa, curving round the hind margin to the hinder angle, where the border ends in a point. Posterior wings rather narrowly bordered with black from below the tip to the anal angle.

Underside paler, posterior wings inclining to whitish ; anterior wings with a row of black dots on the costa and one at the end of the cell; all the hind margins with the ends of the nervures marked with black, which forms a nearly continuous line towards the apex of anterior wings; no discoidal spot on posterior wings.

Antennæ black, the shaft ringed with white.

'The sexes hardly differ. 
Allied to $T$. tenera, Kirb., but differs from all the allied species by the continuous narrow border to the posterior wings.

Hab. Sierra Leone (Preuss).

In the collection of Dr. Staudinger.

\section{Teriomima modesta.}

Exp. rather over an inch.

Male.-Upperside uniform smoky brown; fringes rather paler, spotted neither above nor below.

Underside clearer brown, with white spots. Anterior wings speckled with white at the base; two spots in the cell, above the second is the first of a row of two or three subcostal dots, followed by a transverse row of four larger spots; two submarginal rows of spots (four in each) on the upper half of the wing; below these are two larger ones in a single line; the first spot of the inner series is preceded by a small subcostal dash ; the second and third spots of the outer series have a small dash on the outside, and the fourth spot of the outer series is the smallest, being reduced to a dash. Posterior wings with two large spots on the costa, two in the cell, and a third (double) closing it ; two more rather irregular series of spots below the cell and a double row of submarginal spots, some of the lower ones of the outer row with smaller adjacent dashes on the outside.

Antennæ black, spotted with white on the underside; the club long, gradually formed, and tipped with tawny.

Hab. Cameroons (Preuss).

In the collection of Dr. Staudinger.

Differs from T. adelgitha, Hew., in the unspotted fringes and upper surface.

\section{Teriomima cordelia.}

Exp. nearly an inch.

Upperside purplish blue, shading into dusky towards the apex of the anterior wings; fringes blackish. Thorax clothed with rich purple or green hairs.

Underside brown, speckled with tawny at the base and costa of the anterior wings and on the basal half of the posterior wings. Anterior wings (on their upper two thirds) with two, and posterior wings with three rows of submarginal lines or nearly connected crescents of tawny dusting.

Head with a tawny line within each eye; antennæ black, ringed with white; club gradually formed, tipped with tawny; legs tawny, banded with brown.

Hab. Cameroons (Preuss), Ogowe (Bokh.). 
In the collection of Dr. Staudinger.

Allied to T. dispar, Kirb., and T. melissa, Druce, but differs from the former and apparently also from the latter in the markings of the underside.

\section{Teriomima dubia.}

Exp. 99 inch.

Male.-Upperside brown, distinctly suffused with purple, and with or without a whitish spot beyond the end of the cell of the anterior wings.

Underside brown, with two or three tawny spots or markings in the cells and an indistinct double row of submarginal tawny markings ; the white spot as above on anterior wings, and an interrupted, rather indistinct, tawny stripe running beyond the cell on the posterior wings.

Antennæ black, ringed with white; club tipped with orange. Body rich purple and coppery green in some lights.

Hab. Sierra Leone and Barombi, Cameroons (Preuss).

In the collection of Dr. Staudinger.

Perhaps a variety of $T$. melissa, Druce.

\section{Epitola badura.}

Exp. $1 \frac{1}{3}$ inch.

Male.-Anterior wings rather pointed; posterior wings rounded.

Upperside deep blue. Anterior wings with the costa (broadly), apical third, hind margin, and a basal stripe on the lower part of the cell black; inner margin with a few coppery-green scales. Posterior wings with the costa broadly and hind margin narrowly black.

Underside greyish brown, with a row of submarginal lunules of greyish dusting, within which is a broader stripe of the same kind; across the wings runs an irregular series of lines and zigzags of greyish dusting.

Hab. Cameroons.

In the Hewitson Collection of the British Museum as the male of $E$. cercene, Hew.; and in that of Mr. H. Grose Smith.

Allied to E. dunia, Kirb., but of a deeper blue and without the oblique pale zigzag line on the underside of the anterior wings.

\section{Epitola Staudingeri.}

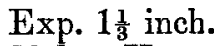

Male.-Upperside bright blue. Anterior wings with the 
costa, apex, and hind margin narrowly black; a very large oblong black blotch projects into the wing from the lower part of the hind margin, filling up the whole space nearly to the cell, from the inner half of the upper discocellular nervure to below the lowest branch of the median nervure. Posterior wings blue, with the costa, inner margin, and fringes black.

Underside uniform greyish brown, without markings. Legs brown, ringed with grey.

Hab. Sierra Leone (Preuss).

In the collections of Dr. Staudinger and of Mr. P. Crowley.

Exp. $1 \frac{1}{4}-1 \frac{1}{3}$ inch.

\section{Epitola zelica.}

Upperside light blue, with a purplish shade in some lights. Anterior wings with the costa above the cell and the apex broadly blackish brown, the dark colour diminishing triangularly to the hinder angle. Posterior wings with the costa above the cell, the inner margin, and the hind margin (narrowly) blackish brown.

Underside white, with an obsolete straight pale yellowish line and two or three obsolete zigzag lines between this and the cell. In the female these indistinct markings are wanting, and there is only a blackish line at the base of the fringes of the anterior wings, which is also present in the male.

The sexes do not differ otherwise.

Hab. Barombi, Cameroons (Preuss).

In the collection of Dr. Staudinger.

Allied to E. zerina, Hew., but in that species the upperside is of a deeper blue and the underside is much more heavily marked.

Exp. $1 \frac{1}{2}$ inch.

\section{Epitola Henleyi.}

Upperside black and deep violet-blue, the blue portions of the wing broken up into spots by black spaces, especially along the nervures.

Underside brown; a pale space on the inner margin of anterior wings, from which two rows of pale submarginal spots run towards the costa-the outermost row formed of three nearly contiguous spots; the innermost row of three spots, of which the two upper ones are contiguous, separated from the third. Posterior wings with traces of two paler bands, parallel to the hind margin. 
Hab. Barombi, Cameroons (Preuss).

In the collection of Dr. Staudinger.

Upperside hardly distinguishable from $E$. hyetta, Hew., with which a specimen of $E$. Henley $i$ from Calabar is placed in the Hewitson Collection of the British Museum; but the underside is very different.

\section{Epitola catuna.}

Exp. 1-1 $\frac{1}{4}$ in.

Male.-Upperside deep purplish blue, with rather broad blackish margins, the nervures narrowly black ; fringes grey.

Underside greyish brown. Anterior wings darker at the base to beyond the cell; at the end of the cell stands an obsolete grey spot; the darker portion of the wing is bounded by a row of obsolete grey spots, much expanded on the inner margin; on the hind margin is a row of obsolete grey lunules, dividing into two rows on the upper half of the wing. Posterior wings with three submarginal rows of broad obsolete grey lunules, the innermost most indistinct.

Antennæ and legs very slightly ringed with white, only the extreme tip of the former tawny.

Hab. Cameroons (Preuss).

In the collection of Dr. Staudinger.

Resembles E. hyetta, Hew., on the upperside, and the group of $E$. cercene, Hew., below.

\section{Epitola doleta.}

Exp. $1 \frac{1}{6}$ inch.

Male. - Upperside blackish brown, with bright blue markings. Anterior wings with scattered blue markings towards the base of the cell, a short bar just beyond the middle of the costa running obliquely outwards, and a band running nearly to the hind margin between the median and submedian nervures. Posterior wings with the whole space between the upper part of the cell and the submedian nervure filled up with blue nearly to the hind margin.

Underside as in $E$. catuna; in one specimen the paler markings are almost entirely obsolete.

Hab. Sierra Leone (Preuss).

In the collection of Dr. Staudinger.

Perhaps the male of $E$. cephena, Hew., which it somewhat resembles on the under surface. 


\section{Epitola perdita.}

Exp. rather over an inch.

Male.-Anterior wings rather pointed, with the hind margin oblique. Posterior wings oblong, nearly rectangular.

Upperside black. Anterior wings rich blue from below the cell to the inner margin. Posterior wings with a large blue patch filling up two thirds of the lower part of the wing, but nowhere extending to the margins.

Underside : Anterior wings slate-colour, with a pale grey spot at the end of the cell and two more, nearly connected, near the hinder angle; apex reddish, edged by a submarginal coppery-green line from near the apex to the middle of the hind margin. Posterior wings reddish, shading into buff towards the base, with a submarginal row of silvery-green lunules, edged with black within and (less distinctly) without. A $\mathrm{Y}$-shaped series of silvery-green markings edged with black lines, not extending to the costa, across the middle of the wing.

Hab. Cameroons.

In the collection of Mr. H. Grose Smith.

\section{Epitola (?) barombiensis.}

Exp. rather more than an inch.

Anterior wings obtusely pointed at the apex, with the hind margin very convex. Posterior wings rounded.

Upperside purplish blue. Anterior wings with the costa, apex, hind margin, and nervures black; cell black, with irregular purplish markings towards the base ; inner margin but thinly scaled with purple. Posterior wings with the costa and inner margin broadly and the hind margin more narrowly black.

Underside grey, a dark brown cloud extending from the base of the inner margin obliquely to beyond the cell ; thence, after an interruption, it spreads more broadly over the whole apical portion of the hind margin, except where it is slightly interrupted towards the costa before the apex. Posterior wings speckled with smoky brown, darkest on the hind margin, where it shades into a broad border, ill-defined towards the base and not extending to the anal angle.

Hab. Barombi, Cameroons (Preuss).

In the collection of Dr. Staudinger. 